\title{
New records of the bryozoan Metrarabdotos from the Pirabas Formation (Lower Miocene), Pará State, Brazil
}

\author{
Laís V. Ramalho, Vladimir A. Távora, and Kamil Zagorsek
}

\begin{abstract}
The Pirabas Formation in Pará State, Brazil, contains a very rich and diverse fauna of Early Miocene age, including several groups of invertebrates and vertebrates. Previous studies of bryozoans from Brazil included two species of Metrarabdotos ones, but these need revision. The present study describes three new species of Metrarabdotos (M. aquaeguttum sp. nov., M. elongatum sp. nov., M. capanemensis sp. nov.) collected from two outcrops: Atalaia Beach at Salinópolis city and B-17 Mine at Capanema city.
\end{abstract}

Laís V. Ramalho. Instituto Español de Oceanografia - IEO, Puerto Pesquero, s/n, Fuengirola. 29640; and Universidad de Málaga, Málaga - España. laiscanabarro@yahoo.com.br

Vladimir A. Távora. Laboratório de Paleontologia, Faculdade de Geologia, Instituto de Geociências, Universidade Federal do Pará, Caixa Postal 1611, Belém, Pará, Brazil. vladimir@ufpa.br Kamil Zagorsek. Department of Geography, Technical University of Liberec, Studentská 2, CZ-461 17 Liberec, Czech Republic. kamil.zagorsek@gmail.cz

Keywords: new species; Lower Miocene; Brazil; Caribbean Biogeographic Province; Bryozoans

Submission: 20 July 2016 Acceptance: 12 June 2017

\section{INTRODUCTION}

Bryozoans are important fossils for geological reconstructions. They have broad stratigraphical distributions and provide evidence for biogeographic, phylogenetic, and environmental interpretations. Studies including bryozoans in Brazilian sedimentary basins are scarce (White, 1887; Maury, 1925; Barbosa, 1957, 1959a, 1959b, 1967, 1971; Távora and Fernandes, 1994; Távora et al., 2010a; Zagorsek et al., 2014; Ramalho et al., 2015), and some need to be revised.
The cheilostome bryozoan genus Metrarabdotos Canu, 1914 comprises 38 fossil and six living species (Bock, 2014). These species, including both fossil and living representatives, are exclusively tropical and northern subtropical (Rosso, 2005; Cheetham et al., 2007). Cheetham (1967) considered that Metrarabdotos probably originated in the Gulf of Mexico region in the Late Eocene and subsequently migrated through the Caribbean and Western Atlantic to Europe and Africa. In the Americas, it has been recorded from southeastern sectors of North America, Central America, and

http://zoobank.org/9788CCA9-C63B-4126-9F51-62446D7BF854

Ramalho, Laís V., Távora, Vladimir A., and Zagorsek, Kamil. 2017. New records of the bryozoan Metrarabdotos from the Pirabas Formation (Lower Miocene), Pará State, Brazil. Palaeontologia Electronica 20.2.32A: 1-11 palaeo-electronica.org/content/2017/1915-metrarabdotos-from-pirabas 
northern Venezuela and Dominican Republic in the Caribbean (Cheetham et al., 2001; 2007). Six species have been described from Brazil, comprising five recent species - Metrarabdotos jani Winston et al., 2014, M. sergipensis Santana et al., 2009, M. gulo (Marcus, 1955), M. unguiculatum Canu and Bassler, 1928, and M. tuberosum Canu and Bassler, 1928 - and one fossil species - M. moniliferum (Milne Edwards, 1836) (Canu and Bassler, 1928; Marcus, 1955; Barbosa, 1967; Távora and Fernandes, 1994; Cheetham et al., 2007; Santana et al., 2009; Távora et al., 2010a; Winston et al., 2014). Metrarabdotos moniliferum was recorded from Miocene sediments of the Marajó Basin (Barbosa, 1967), but those specimens need to be reexamined as the species was originally described from Pliocene deposits from near the North Sea and the English Channel (Rosso, 2005; Cheetham et al., 2007). The recent species $M$. gulo was regarded by Cheetham et al. (2007) as a possible synonym of $M$. auriculatum Canu and Bassler, 1923 and M. tuberosum Canu and Bassler, 1928, but this can't be ascertained because the holotype of $M$. gulo has not been located (Cheetham et al., 2007, p. 41-42).

The present study describes three taxa collected from the Pirabas Formation, showing that Metrarabdotos is relatively well represented in this formation.

\section{MATERIAL AND METHODS}

\section{Study Area}

The Pirabas Formation (Maury, 1925), represents one of the most important documentations of a marine transgressive event in northern Brazil during the Miocene (Távora et al., 2013; Antonioli et al., 2015). It crops out discontinuously in the northern Brazilian states of Pará, Maranhão, and Piauí, providing some of the best marine fossil occurrences for the entire Cenozoic. Following Rossetti and Góes (2004) and Távora et al., (2010b), it deposited along the southern limit of the Caribbean Miocene paleobiogeographic province. Samples were collected from outcrops at four different areas (Figure 1): Atalaia Beach (Salinópolis city), B-17 Mine (Capanema city), Fortaleza Island, and Aricuru (Maracanã city). Metrarabdotos colonies were found only in samples from the first two localities.

The samples were treated following Zargorsek and Vávra (2000), at the Laboratório de Oceanografia Geológica (Universidade Federal do Rio Grande - FURG) and Laboratório de Paleonto-

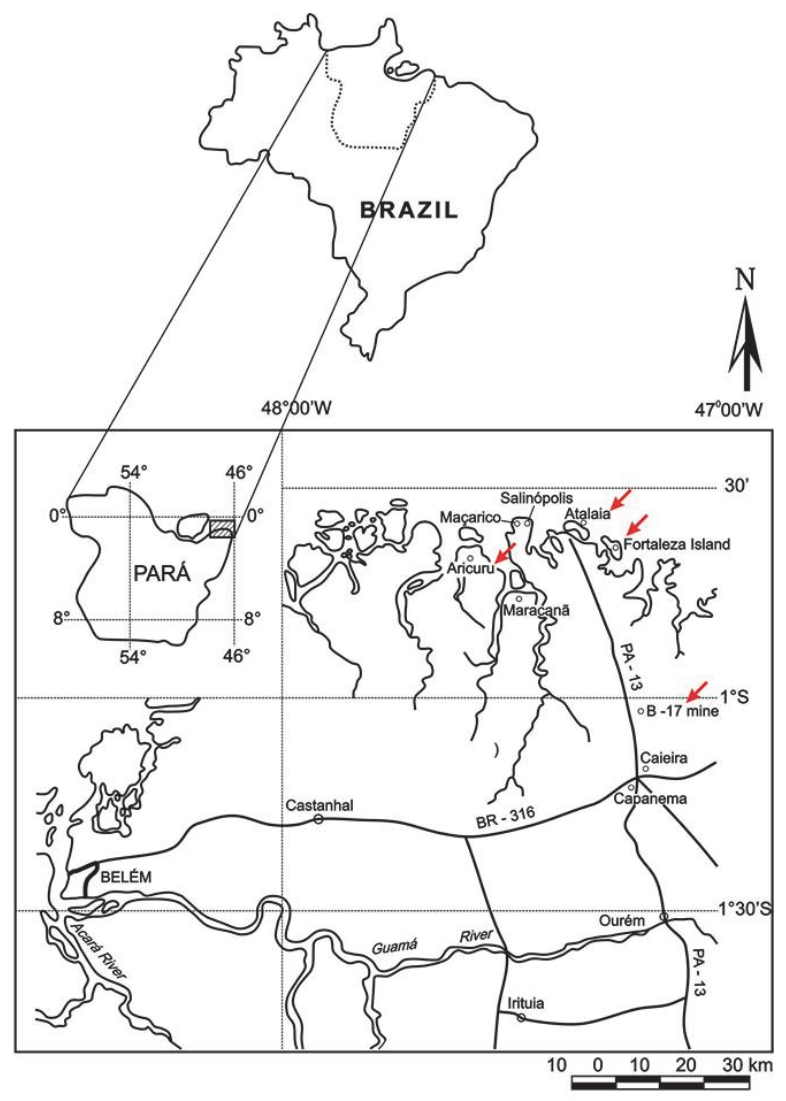

FIGURE 1. Map of the study area showing the four outcrops (arrows).

logia (Universidade Federal do Pará - UFPA). Scanning Electron Microscopy was undertaken at the Museu Nacional (Rio de Janeiro, BR - Centro de Microscopia Eletrônica), Universidade Federal do Pará (Belém, BR), the Natural History Museum (London, UK), and the Universidad de Malaga (Spain). Measurements ( $N=10$, if not indicated otherways) are given in micrometers as ranges with the mean in bracket square: minimun-maximun [mean]. The material is stored in the paleontological collections of the Geoscience Museum (UFPA) under the code number MG-6303-I. The comparisons (measurements and features) among species discussed in this study were made from the original description of each species and other descriptions available from literature such as Canu and Bassler (1919), Canu and Bassler (1928), Cheetham (1968), and Cheetham et al. (2007).

\section{RESULTS}

\section{Taxonomy}

We mainly followed the glossary for Metrarabdotosidae reported by Cheetham et al. (2007) and 
on the website (www.bryozoa.net) but, following Ostrovsky (2014) we preferred ooecium rather than ovicell.

Suborder FLUSTRINA Smitt, 1868 Superfamily LEPRALIELLOIDEA Vigneaux, 1949 Family METRARABDOTOSIDAE Vigneaux, 1949 Genus METRARABDOTOS Canu, 1914

Diagnosis. From Cheetham, Sanner, and Jackson (2007) modified. Colonies rigidly erect or encrusting. Frontal shield imperforate except for areolae on proximal and lateral margins. Primary orifice with distal shelf. Secondary orifice with one to three denticles on or just below proximal lip. No oral spines. Adventitious avicularia with different size and orientations, single or paired, dimorphic. Mandibles hinged on complete pivotal bars. Ordinary avicularia single or paired on autozooecia, present or absent on ovicellate autozooecia; special avicularia can be present on zooecia adjacent to the ooecium and/or in zooecia located along branch edges. Ooecium nearly as large as a zooid, sometimes even larger, fused skeletally with the maternal zooecium.

Remarks. Cheetham, Sanner, and Jackson (2007) did not refer to ooecia, which are larger than zooids. However, in $M$. elongatum sp. nov. we found ooecia larger than maternal zooid, while this species without any doubt belongs to genus Metrarabdotos. We therefore modified the diagnosis in this sense.

Metrarabdotos aquaeguttum sp. nov.

Figure 2.1-4

\section{zoobank.org/943B93BE-B715-4836-B69D-904BEFFF17AA}

Examined specimens. Holotype: MG-6303-I-a: fertile fragment; $9 \mathrm{~mm}$ long $\times 4 \mathrm{~mm}$ wide; Paratype: Atalaia Beach (Salinópolis city): MG-6303-I - b, fertile branch fragment, $5 \mathrm{~mm}$ long $\times 4 \mathrm{~mm}$ wide; MG6303-I - c, fertile branch fragment, $5 \mathrm{~mm}$ long $\times 3$ $\mathrm{mm}$ wide; MG-6303-I - d, fertile branch fragment, 6 $\mathrm{mm}$ long x $4 \mathrm{~mm}$ wide; MG-6303-I - e, infertile branch fragment, $3 \mathrm{~mm}$ long $\times 4 \mathrm{~mm}$ wide; B- 17 mMine (Capanema city) MG-6303-I - f, fertile branch fragment, $10 \mathrm{~mm}$ long $\times 4 \mathrm{~mm}$ wide; MG6303-I - g, fertile branch fragment, $3 \mathrm{~mm}$ long $\times 4$ $\mathrm{mm}$ wide.

Etymology. The name aquaeguttum is the latinization for "water drop," referring to the shape of the ordinary avicularia in this species.

Diagnosis. Colony erect forming rigid, flat branches, each branch with 12-20 longitudinal zooidal series. Orifice tridenticulate. Ordinary avicularia paired, rarely single, very small, drop-like, located alongside latero-distal margins of the ori- fice, directed proximally and slightly curved inwards; special avicularia approximately three times longer than ordinary ones, elongated with a rounded spatulate tip, located distally to the orifice. Ooecium elongated, semi elliptical to triangular, with about 15 narrow ribs, usually separated each other by two-to-three rows of pores.

Description. Colony erect forming rigid, flat branches, each branch with 12-20 longitudinal zooidal series (Figure 2.1).

Autozoecia elongate (400-833 [average 647] $\mu \mathrm{m}$ length $\times 125-300$ [233] $\mu \mathrm{m}$ width), frontal wall flat, smooth, or slightly granular with 17-23 areolar pores around lateral and proximal margins (Figure 2.2). Peristome slightly elevated, hiding the primary orifice. Secondary orifice longitudinally elongate, oval (100-200 [155] $\mu \mathrm{m}$ long x 100-143 [118] $\mu \mathrm{m}$ wide) with a broad, irregular sinus, one median denticle (frequently broken) (Figure 2.2-4), and a pair of lateral denticles.

Ordinary avicularia on autozoecia as well as in ovicellate zooecia, frequently paired, rarely single, almost equal in size (56-89 [68] $\mu \mathrm{m}$ long), smaller than regular areolar pore, drop-like shaped: premandibular portion rounded, located level to the distal edge of peristome, rarely at its mid length; mandibular portion triangular with pointed rostrum; directed proximally and slightly curved inwards (Figure 2.2-4). Special avicularia approximately three times (in average) longer than the ordinary ones usually developed on zooecia adjacent to ooecia (Figure 2.3-4) and on marginal zooecia (Figure 2.2), usually paired with an ordinary avicularium; mandibular portion elongate, rostrum with slightly curved sides, and rounded spatulate tip; size can be very variable in the same colony (122-400 [254] um length); pivotal bar frequently broken. Premandibular and part of mandibular portion located above the distal margin of the peristome, mandibular portion directed proximally, often slightly towards midline.

Maternal zooid long (800-1150 [964] $\mu \mathrm{m}$ including the ooecium) with very narrow, transversally elongated orifice, proximal lip moderately developed, not thickened, and distal lip lightly upturned medially to form a curved proximal border of the ooecium; a pair of ordinary avicularia in maternal zooecia have comparable shape and size (56-89 [73] $\mu \mathrm{m}$ long) than those found on autozoecia and are placed at the lateral ends of the orifice, pointing proximally and slightly medially (Figure 2.4); ooecium longer than wide (400-571 [492] $\mu \mathrm{m}$ long and $x$ 300-500 [412] $\mu \mathrm{m}$ wide), semi elliptical to triangular, surface moderately convex, sculp- 

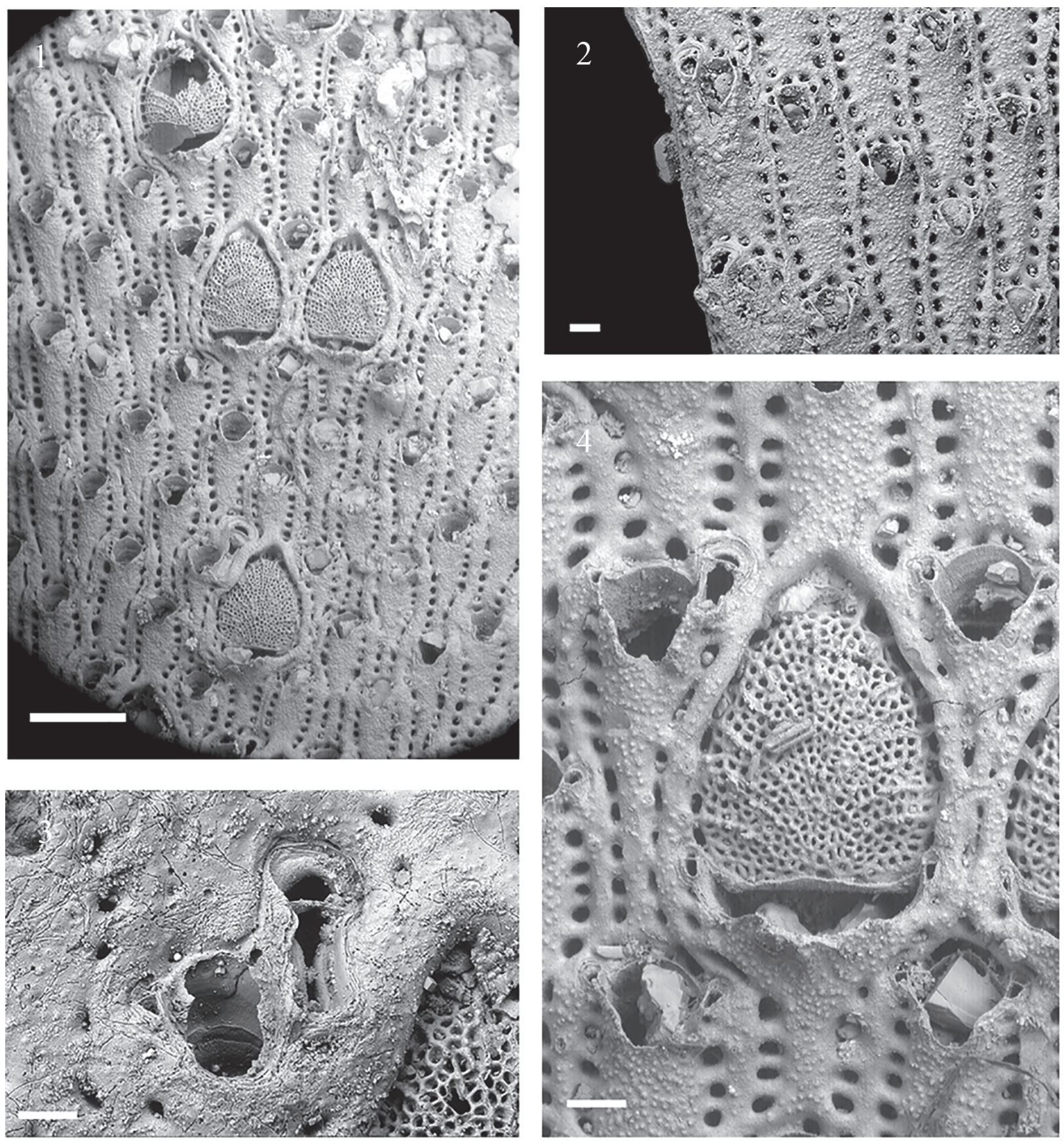

FIGURE 2. Metrarabdotos aquaeguttum sp. nov. 1. General view of the colony fragment with infertile and fertile zoecia. 2. Detail of a branch edge showing special and ordinary avicularia. 3. Detail of zooids adjacent to a maternal one showing orifice, special avicularium paired with an ordinary one, and part of the ooecium. 4. Detail of maternal zooid with a complete ooecium, ordinary avicularia, and a zooid adjacent to maternal one, with a special avicularium. Scale bars equal 1: $500 \mu \mathrm{m}$; 2: $100 \mu \mathrm{m} ; 3: 40 \mu \mathrm{m}$; 4: $200 \mu \mathrm{m}$. 1, 4: MG-6303-I-b; 2: MG-6303-I-c; 3: MG-6303-I-a.

tured by 15 thin diverging and slightly arcuated ribs, separated from each other by two-to-three rows of pores (Figure 2.1, 2.4). Areolar pores uniform around the margin, except at the distal region where they are slightly larger (Figure 2.1, 2.4).
Remarks. This species shows a great variability in size and shape of the special avicularia, but the other characters (ordinary avicularia, orifice and ooecium) are more stable. 
Metrarabdotos aquaeguttum is distinguished from the other species described here principally by the shape, size, and location of the ordinary avicularium. M. elongatum sp. nov. has larger ordinary avicularia, rostrum elongate, straight or with one side curved ending in a rounded to quadrate tip; avicularia of maternal zooecia are larger and more inwardly directed. Metrarabdotos tuberosum Canu and Bassler, 1928 described previously to Brazil and M. auriculatum Canu and Bassler, 1923, which has a similar ordinary avicularia, differ from $M$. aquaeguttum as they have a bidenticulate orifice (lacking the median denticle). The next two species have ordinary avicularia with similar shape and occupying almost the same position than $M$. aquaeguttum but they can be distinguished as $M$. floridanum (Cheetham, 1968) has larger autozoecia, a bifid median denticle, smaller (81-185 $\mu \mathrm{m}$ length) special avicularia with straight rostrum, maternal zooid with distal lip moderately to strongly upturned and proximal lip thickened by coarser tubercles, ooecium larger (609 $\mu \mathrm{m}$ long x $585 \mu \mathrm{m}$ wide) with strong and granulated ribs; and $M$. micropora (Gabb and Horn, 1862) has secondary orifice with short, blunt lateral denticles commonly visible in frontal view; some ordinary avicularia placed midline and proximally, mandibular portion sub-triangular, rostrum straight and slightly rounded tip; special avicularia smaller in size (special: 83-156 $\mu \mathrm{m}$ long), with rostrum elongate, straight and with rounded tip; ooecium slightly wider than long $(531 \mu \mathrm{m}$ long $\times 583 \mu \mathrm{m}$ wide) with strong, coarsely granulated ribs.

Range. Lower Miocene.

Occurrence. Pirabas Formation: Atalaia Beach, Salinópolis city and B-17 Mine, Capanema city, Pará state.

\section{Metrarabdotos elongatum sp. nov. Figure 3.1-6}

\section{zoobank.org/2CE3BC56-8BBB-4D10-888C-E032CAE9F443}

Referred specimens. Holotype: MG-6303-I - i, B17 Mine, fertile branch fragment, $10 \mathrm{~mm}$ long $\times 4$ $\mathrm{mm}$ wide; Paratype: Atalaia Beach (Salinópolis city): MG-6303-I - h, fertile branch fragment, $4 \mathrm{~mm}$ long $\times 3 \mathrm{~mm}$ wide; MG-6303-I - I, infertile branch fragment, $4 \mathrm{~mm}$ long $\times 3 \mathrm{~mm}$ wide; MG-6303-I - $\mathrm{m}$, fertile branch fragment, $8 \mathrm{~mm} \times 5 \mathrm{~mm}$; MG-6303-I $\mathrm{n}$, infertile branch fragment, $5 \mathrm{~mm}$ long $\times 5 \mathrm{~mm}$ wide; MG-6303-I - o, fertile branch fragment, $4 \mathrm{~mm}$ long x $5 \mathrm{~mm}$ wide; MG-6303-I - $\mathrm{p}$, infertile branch fragment, $41 \mathrm{~mm}$ long $\times 12 \mathrm{~mm}$ wide; MG-6303-I $\mathrm{q}$, fertile branch fragment, $5 \mathrm{~mm}$ long $\times 4 \mathrm{~mm}$ wide; MG-6303-I - r, fertile branch fragment, $11 \mathrm{~mm}$ long $x 5 \mathrm{~mm}$ wide.
B-17 Mine (Capanema city): MG-6303-I - j, infertile branch fragment, $2 \mathrm{~mm}$ long $\times 3 \mathrm{~mm}$ wide; MG-6303-I - k: fertile branch fragment, $6 \mathrm{~mm}$ long $\mathrm{x}$ $4 \mathrm{~mm}$ wide; MG-6303-I - s, fertile branch fragment, $8 \mathrm{~mm}$ long $\times 5 \mathrm{~mm}$ wide.

Etymology. The name elongatum is the latinized word for "elongate," referring to the shape of the rostrum of the avicularium.

Diagnosis. Colony erect, bilamilate; orifice circular to ellipsoidal, tridenticulate. Ordinary avicularia often paired, pre-mandibular portion located above or level to distal margin of the orifice, rarely midline or proximally; rostrum elongated, straight or with one side curved, ending in a curved triangular or quadrate-spatulate tip. Special avicularia large on zooecia adjacent to ooecia and slightly smaller on common zooecia; pre-mandibular portion placed very distally to secondary orifice; mandibular portion elongate, narrower in the middle part and ending in a spatulate or rounded tip. Ooecium longer than wide, the surface moderately flat and perforated by pores between weak ribs.

Description. Colony erect, bilamilate with 14-21 zooecia disposed alternately in longitudinal series (Figure 3.1).

Ordinary autozooids rectangular, longer than wide (409-733 [578] $\mu \mathrm{m}$ long x 144-277 [208] $\mu \mathrm{m}$ wide). Frontal wall finely tuberculate, flat; $15-23$ sunken areolare around the lateral and proximal border (Figure 3.2). Primary orifice hiding by the peristome; secondary orifice almost circular to ellipsoidal, almost as long as wide (100-167 [134] $\mu \mathrm{m}$ long $\times 100-180$ [131] $\mu \mathrm{m}$ wide) with a broad $U$ shaped sinus bearing a prominent median denticle (Figure 3.2-3) and a pair of lateral denticles (orifice tridenticulate) (Figure 3.4).

Ordinary avicularia (67-229 [130] $\mu \mathrm{m}$ long) paired in most zooecia, including the maternal ones almost equal in size and position (Figure 3.23 ), infrequently single; pre-mandibular portion frequently placed above or level to the distal margin of the secondary orifice, rarely midline or more proximally; mandibular portion elongate, the tip touching lining the lateral margin of the orifice; rostrum straight to curved and narrowed but ending in a curved triangular or quadrate-spatulate tip, directed proximally and sometimes slightly inward; crossbar complete (Figure 3.2-3). Special avicularia variable in size (122-356 $\mu \mathrm{m}$ long), longer on zooecia adjacent to ooecia, and slightly smaller on common zooecia. Avicularia on the marginal zooecia usually comparable to those of the central zooecia, sometimes slightly longer (Figure 3.1, 3.56). Special avicularia with pre-mandibular region 

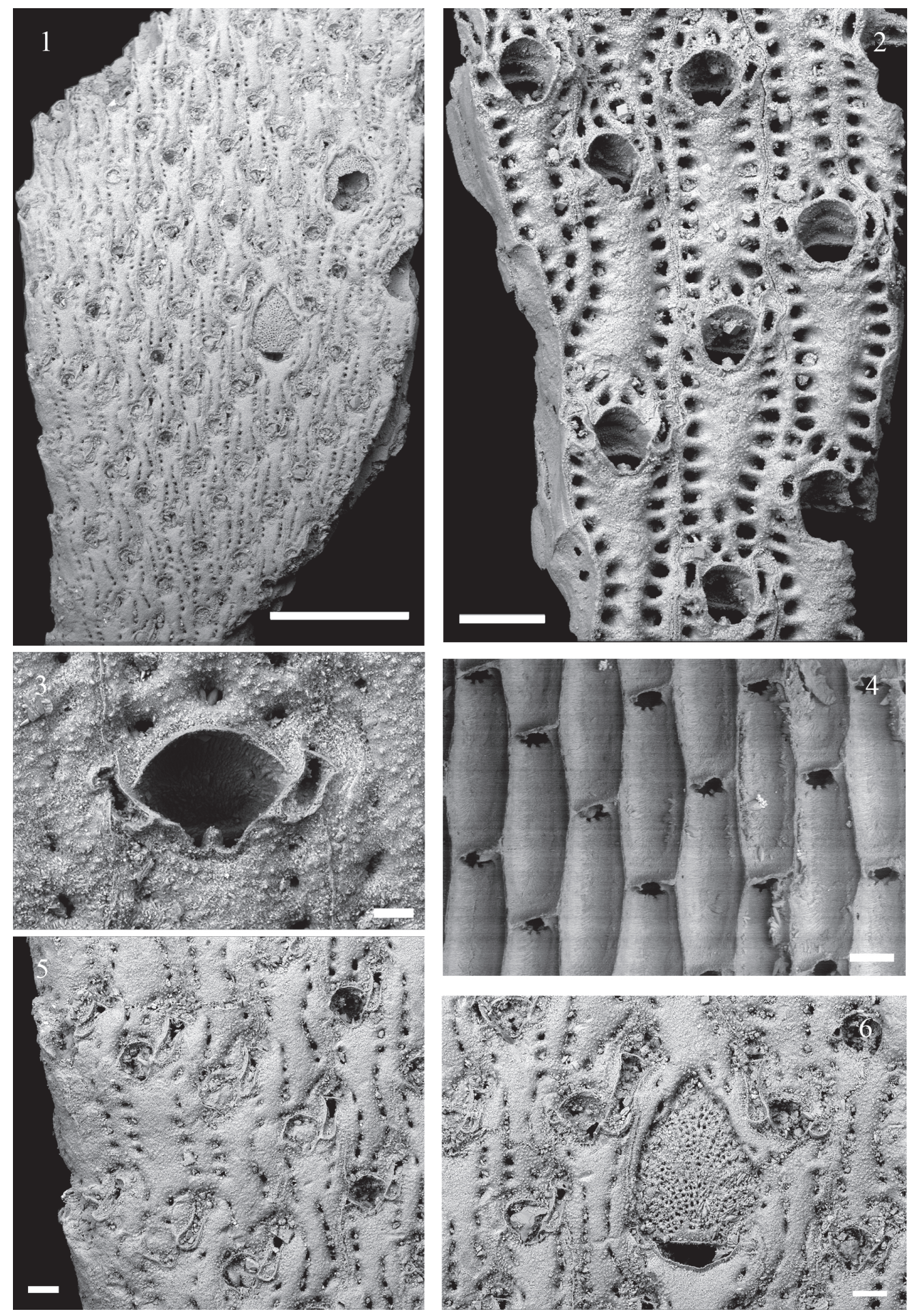

FIGURE 3. Metrarabdotos elongatum sp. nov. 1. General view of a fragment showing some fertile and infertile zooecia. 2. Detail of some zooecia showing orifice with median denticles, paired avicularia, and areolar pores. 3 . Detail of the secondary orifices showing a median denticle and a pair of laterally ordinary avicularia. 4. Internal view of some zooecia showing tridenticulate orifices. 5. Detail of the branch edge showing zooecia with large ordinary avicularia. 6 . A maternal zooid with complete ooecium and paired ordinary avicularia surrounded by zooecia, each with a special avicularium paired with an ordinary one, and by infertile zooecia with paired ordinary avicularia. Scale bars equal 1: 500

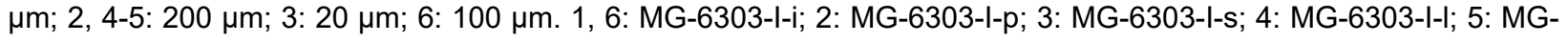
6303-I-h. 
placed very distally in relation to the orifice, and their proximal portion is in the midline of the orifice; mandibular portion elongate, ending in a spatulate or rounded tip; rostrum straight or with one or both sides curved and tip directed (lining) to orifice (proximally and medially). Maternal zooecia elongated (704-1267 [938] $\mu \mathrm{m}$ long) with crescent-like orifices (180-400 [242] $\mu \mathrm{m}$ wide) (Figure 3.1, 3.6), distal lip poorly developed, upturned forming the narrow and straight proximal border of the ooecium, proximal lip not protruded, smooth; one pair of ordinary avicularia located near the proximal corners, unequal in size (76-114 [100] $\mu \mathrm{m}$ long), similar in shape to those on the zooecia; directed proximally and inward (Figure 3.6). Ooecium longer than wide (360-533 [470] $\mu \mathrm{m}$ long $\times 322-467$ [367] $\mu \mathrm{m}$ wide), with a sub-triangular to arcuate distal end; surface moderatelly flat perforated by pores between weak ribs, and bordered by larger areolar pores, mostly along the distal end (Figure 3.1, 3.6).

Remarks. The elongate shape, size, and position of the ordinary avicularia distinguish this species from others described in this study and from those previously known. Metrarabdotos colligatum Canu and Bassler, 1919 has similar special avicularia but it can be distinguished for the secondary orifice with two or rarely three denticles, the smaller ordinary avicularium that is triangular and placed level to the orifice; the absence of avicularia associated to ooecia.

Range. Lower Miocene.

Occurrence. Pirabas Formation: Atalaia Beach, Salinópolis city, and B-17 Mine, Capanema city, Pará state.

\section{Metrarabdotos capanemensis sp. nov.} Figure 4.1-3

\section{zoobank.org/CF64D724-C6F1-44DC-93AA-F32507CE7517}

Referred specimens. Holotype: MG-6303-I-t; B17 Mine; fertile branch fragment; $5 \mathrm{~mm}$ long $\times 3$ $\mathrm{mm}$ wide; Paratype: MG-6303-I-u, B-17 Mine; fertile branch fragment; 2 long $\mathrm{mm} \times 2 \mathrm{~mm}$ wide.

Etymology. The name capanemensis refers to Capanema, the city near B-17 Mine, where this species was found.

Diagnosis. Colony erect, bilaminate; orifice without median denticle. Ordinary avicularia paired, falciform, located proximally, and lining the secondary orifice. Special avicularia large, elongated, narrow and with rounded tip, sparse, apparently not associated to zooecia adjacent to maternal ones.

Description. Colony erect, bilaminate; available branch fragments $2-5 \mathrm{~mm}$ long $\times 2-3 \mathrm{~mm}$ wide.
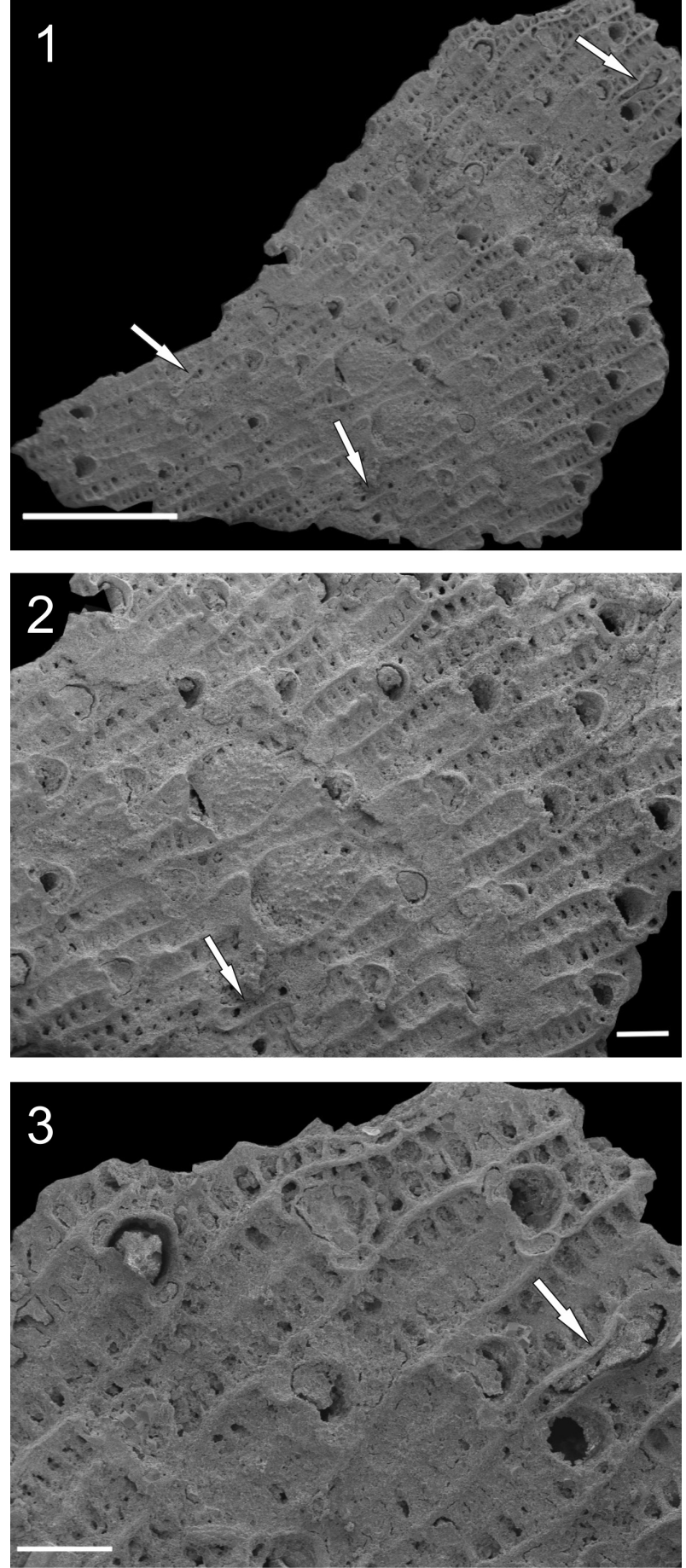

FIGURE 4. Metrarabdotos capanemensis sp. nov. 1. General view of a colony showing fertile and infertile zooecia. 2. Detail showing two maternal zooecia bearing complete ooecia, flat ordinary zooecia and a large special avicularium below the maternal zooid. 3. Some zooecia with paired, ordinary proximally located avicularia and one elongated special avicularium. Note the frontal shield with elliptical areolar pores and a median longitudinal keel. Scale bars equal 1: $1000 \mu \mathrm{m} ; 2-3: 200$ um. 1-3: MG-6303-I-t. Arrows indicate special avicularia. 
Autozoecia rectangular (489-667 [600] $\mu \mathrm{m}$ long $\times$ 222-267 [253] $\mu \mathrm{m}$ wide) with flat frontal wall, often developing a median keel. 14-19 areolar pores on each autozoecium, very large, elliptical, and transversally elongated leaving only a thin medial portion of unperforated frontal surface (Figure 4.1-3). Primary orifice hidden by the peristome; secondary orifice slightly wider than long $(120-147$ [149] $\mu \mathrm{m}$ long $x$ 133-160 [149] $\mu \mathrm{m}$ wide; $N=6$ ) with proximal border almost straight or sometimes convex (Figure 4.2-3), lacking median denticles.

Ordinary avicularia paired (93-107 [105] $\mu \mathrm{m}$ long), falciform, with extremely curved mandibular part situated proximally, lining the secondary orifice (Figure 4.2-3). Special avicularia very large (440467 [453] $\mu \mathrm{m}$ long; $\mathrm{N}=3$ ) almost as long as autozooecia, elongated, directed proximally; rostrum elongated, narrow and with rounded tip; pre-mandibular portion and part of the mandibular portion located very distally to the orifice and nearly at the midlenght of the distal zooecium, the tip of the mandibular portion ending near to the proximal margin of the orifice or slightly proximally (Figure 4.1-3). Special avicularia sparse, apparently not associated to zooecia adjacent to maternal ones (Figure 4.1-3).

Maternal zooecia large (911-956 [933] $\mu \mathrm{m}$ long; $N=3$ ) with proximal lip enlarged developing lateral protuberances; ooecium slightly longer than wide (400-467 [433] $\mu \mathrm{m}$ long $\times 356 \mu \mathrm{m}$ wide; $\mathrm{N}=$ 3 ) with frontal shield perforated by minute pores and prominent, curved ribs (Figure 4.2).

Remarks. The two available specimens consist of unilaminar fragments, resulting from the separation of colony branches along the median lamina. The presence of special avicularia very large and elongated, straight along the zooidal boundaries and very distally placed, pointed proximally, as well as the ordinary falciform avicularia lining the secondary orifice, distinguish $M$. capanemensis sp. nov. from all other species of the genus.

Another similar species is $M$. kugleri Cheetham, 1968, which has ordinary avicularia directed inward and proximally on proximal margin of the secondary orifice, but the ordinary avicularia are triangulars, usually single and larger (140-152 $\mu \mathrm{m}$ long), special avicularia placed on zooids adjacent to ooecia, orifice with broad, rounded Vshaped sinus, and three deep-set denticles; smaller areolar pores.

Range. Lower Miocene.

Occurrence. Pirabas Formation: B-17 Mine, Capanema city, Pará state.

\section{DISCUSSION AND CONCLUSION}

The Metrarabdotos species described from Pirabas sections show high variability in the size, shape, and location of ordinary avicularia as well as the special avicularia. The size, shape, and position of the ordinary avicularia dividing, however, Pirabas Metrarabdotos from the other species from other localities. The presence of ordinary avicularia in majority of the known species of Metrarabdotos is almost unknown or has the minute importance for their taxonomy (see Cheetham et al., 2007). All the species described here have well developed ordinary avicularia and their morphology play the important role in distinguishing them. The presence and diversity of ordinary avicularia can be therefore regarded as specific for the Pirabas species and perhaps evolved in this environment.

The high variability of one feature in one locality has also been observed in other species of Metrarabdotos (Cheetham et al., 1999). The evolution of Metrarabdotosidae expresses high parallel and convergent evolution depending of the local environment, which made the species identification quite complex and difficult.

The distribution of the described species is not homogenous. In Atalaia beach only two species $M$. aquaeguttum sp. nov., and $M$. elongatum sp. nov. were found whereas at Capanema all species co-occurred; Metrarabdotos aquaeguttum sp. nov. is the most common species in Atalaia beach together with $M$. elongatum sp. nov. The lithological setting at the B-17 Mine includes carbonatic and carbonatic-siliciclastic facies, and the fossil content presents typical species of lagoonal environment as dominance of benthic foraminifera Ammonia beccarii, Criboelphidium poeyanum and Elphidium galvestonense, the ostreidae Crassostrea distans, the mytilidae Mytilus canoasensis, the vidali pectinids, the bivalvs Amusium papyraceum, Chlamys indissolubilis, C. (Argopecten) daidela, and $C$. (A.) tetristriata, the crabs Acanthocarpus obscurus, Callapa circularis, Portunus haitensis, $P$. spinimanus, and Tetraxanthus rathbunae, the balanidae Balanus eburneus and $B$. improvisus, the echinoid Abertella complanata, the crustaceans and the Thalassinoides ichnofossils (Távora et al., 2010; Távora et al., 2013). Besides that, the occurrence of marine taxa at the B-17 Mine related to benthic foraminifera Amphistegina, Bolivina, Cibicides and Archaias, the bivalvs Clementia and Ventricolaria, the gastropods Tritonidea, Trophon and Cypraea, the decapod crustacean Pinnixa, and the echinoids Cidaris and Prionocidaris as well 
as the presence of Metrarabdotos with very fragmented colonies and poorly preserved also show evidences of transport and abrasion, suggesting they were allochtonnous, and they were transported from the marine environment to a lagoonal site of burial through tidal channels during strong storms (Távora et al., 2004; Távora et al., 2013; Távora and Reis, 2015).

Fossil occurrences of Metrarabdotos are very useful to locate subtropical and tropical provinces in the past as recent species of the genus occur within the tropical zone and fossil species have a narrow distribution, which apparently was thermally controlled (Cheetham, 1967; Rosso, 2005; Cheetham et al., 2007; Zagorsek et al., 2011). Thus, as expected, the presence of Metrarabdotos corroborates previous inferences of a tropical palaeoenvironment for the Pirabas Formation (Távora and Fernandes, 1999; Távora et al., 2004; Távora et al., 2010b; Távora et al., 2013).

Despite Metrarabdotos species of the Pirabas Formation resemble those found in the Caribbean biogeographical province in Tropical West Atlantic, Dominican Republic, Venezuela, Panamá, and Trinidad. Species described here have unique features and, to the best of our knowledge, seem to be endemic to the Pirabas Formation. The distinctness of the bryozoan association occurring in this formation is corroborated by the co-occurrence of further three species Hippopleurifera barbosae Ramalho et al., 2015, H. confusa Ramalho et al., 2015, and Pirabasoporella atalaiaensis Zagorsek et al., 2014 so far known exclusively from this area (Zagorsek et al., 2014; Ramalho et al., 2015). Reis (2005) and Távora et al. (2010b) also showed similarities between faunas from the Pirabas Formation and the Caribbean biogeographical province analyzing echinoderm, coral, ostracod, and fish communities. However, Aguillera and Páes (2012) based on the whole Pirabas Formation fauna, concluded that diversity as well as pale oceanographic condition and ecosystems were distinctive and different from those of Caribbean biogeographical province.

Further study is needed for a better understanding of this complex South American Miocene Formation.

\section{ACKNOWLEDGEMENTS}

We thank the Departamento Nacional de Produção Mineral (DNPM) for permission to sample the material in Brazil, and "Cimentos do Brasil S.A. - Cibrasa" for authorization to collect at the B-17
Mine. We are grateful to A.P. Correa and C.N. Lamarão (Instituto de Geociências, Laboratório de Microscopia Eletrônica de Varredura, UFPA), A.G. Veiga (Centro de Microscopia Eletrônica do Museu Nacional - Rede Temática Monitoramento Ambiental Marinho, SAPE 4600225483), and Goyo (Centro de microscopia of the Malaga University) for SEM pictures; to Dr. P.D. Taylor, Dr. S. Gofas and Dra. C. Salas, and Dr. L. Calliari for the infrastructure at Natural History Museum (London), Universidad de Malaga (Spain), and Universidade Federal do Rio Grande (Brazil), respectively. To Paul Taylor for suggestions and review in this manuscript. This research was supported by Post-doctoral Fellowship-CNPq for LVR (Science without Border Program - Number: 203242/2014-9) and by the Grant Agency of the Czech Republic for KZ, project number 205/09/0103: "Shallow water ecosystems from the Middle Miocene of the Central Paratethys: Succession and interactions between inorganic and organic elements of the ecosystems.".

\section{REFERENCES}

Aguillera, O. and Paes, E.T. 2012. The Pirabas Formation (Early Miocene from Brazil) and the Tropical Western Central Atlantic Subprovince. Boletim do Museu Paraense Emílio Goeldi. Ciencias Naturais, 7:29-45.

Antonioli, L., Távora, V.A., and Dino, R. 2015. Palynology of carcinolites and limestones from the Baunilha Grande Ecofacies of the Pirabas Formation (Miocene of Pará state, northeastern Brazil). Journal of South American Earth Sciences, 62:134-147.

Barbosa, M.M. 1957. Redescrição do exemplar-tipo de Lunulites pileolus White, 1887. Boletim do Museu Nacional, n.s., Geologia, 24:1-6.

Barbosa, M.M. 1959a. Descrição de um novo briozoário da Formação Pirabas. Boletim do Museu Nacional, n. ser., Geologia, 29:2-3.

Barbosa, M.M. 1959b. Steginoporella pirabensis n. sp. de briozoário da Formação Pirabas, Estado do Pará - Brasil. Anais da Academia Brasileira de Ciências, 31:109-111.

Barbosa, M.M. 1967. Briozoários fósseis da Bacia Amazônica I. Atas do Simpósio sobre a biota Amazônica, 1:75-82.

Barbosa, M.M. 1971. Cupuladria canariensis (Busk) no Brasil. Boletim do Museu Nacional, n.s., Geologia, 35:1-6.

Bock, P. 2014. Metrarabdotos. accessed 18 July 2016. The Bryozoan Home Page. bryozoa.net/cheilostomata/metrarabdotosidae/metrarabdotos.html

Canu, F. 1914. Les bryozoaires fossiles des terrains du Sud-Ouest de la France. VIII. Rupélien de Gaas. Bulletin de la Societé Géologique de France, 14:465474. 
Canu, F. and Bassler, R. S., 1919. Fossil Bryozoa from the West Indies. Publications of the Carnegie Institution, 291:75-102.

Canu, F. and Bassler, R.S. 1923. North American later Tertiary and Quaternary Bryozoa. United States National Museum Bulletin, 125:1-302.

Canu, F. and Bassler, R.S. 1928. Bryozoaires du Brésil. Bulletin de la Société des Sciences de Seine-et-Oise, 9:58-110.

Cheetham, A.H. 1967. Paleoclimatic significance of the bryozoan Metrarabdotos. Gulf Coast Association of Geological Societies, 17:400-407.

Cheetham, A.H. 1968. Morphology and systematics of the bryozoan genus Metrarabdotos. Smithsonian Miscellaneous Collections, 153:1-121.

Cheetham, A.H., Jackson, J.B.C., and Sanner, J. 2001. Evolutionary significance of sexual and asexual modes of propagation in Neogene species of the bryozoan Metrarabdotos in tropical America. Journal of Paleontology, 75:564-577.

Cheetham, A.H., Jackson, J.B.C., Sanner, J., and Ventocilla, Y. 1999. Neogene cheilostome Bryozoa of Tropical America: comparison and contrast between the Central American isthmus (Panama, Costa Rica) and the north-central Caribbean (Dominican Republic), 357:159-192. In Collins, L.S. and Coates, A.G. (eds.), Bulletins of American Paleontology, Paleontological Research Institution, New York.

Cheetham, A.H., Sanner, J., and Jackson, J.B.C. 2007. Metrarabdotos and related genera (Bryozoa: Cheilostomata) in the Late Paleogene and Neogene of tropical America. Journal of Paleontology, 81:1-91.

Gabb, W.M. and Horn, G.H. 1862. The fossil Polyzoa of the Secondary and Tertiary Formations of North America. Journal of the Academy of Natural Sciences of Philadelphia, 5:111-179.

Marcus, E. 1955. Notas sôbre briozoos marinhos brasileiros. Arquivos Museu Nacional do Rio de Janiero, 42:273-342.

Maury, C.J. 1925 Fósseis terciários do Brasil com descrição de novas formas cretáceas. Serviço Geológico e Mineralógico do Brasil, Monografia, 4:1665.

Milne-Edwards, H. 1836. Observations sur les Polypiers fossiles, du genre Eschare. Annales des Sciences naturelles, Zoologie and Biologie animale, 6:321345.

Ostrovsky, A.N. 2014. Evolution of Sexual Reproduction in Marine Invertebrates: Example of Gymnolaemate Byozoans. Springer, Dordrecht.

Ramalho, L.V., Távora, V.A., Tilbrook, K.J., and Zagorsek, K. 2015. New species of Hippopleurifera (Bryozoa, Cheilostomata) from the Miocene Pirabas Formation, Pará state, Brazil. Zootaxa, 3999:125134.

Reis, M.A.F. 2005. Chondrichthyan fauna from the Pirabas Formation, Miocene of Northern Brazil, with comments on paleobiogeography. Anuário do Instituto de Geociências, 28:31-58.
Rossetti, D.F. and Góes, A.M. 2004. Geologia, p. 13- 52. In Rossetti, D.F. and Góes, A.M. (eds.), O Neógeno da Amazônia Oriental. Museu Paraense Emílio Goeldi, Belém.

Rosso, A. 2005. Metrarabdotos (Bryozoa, Cheilostomatida) from Plio-Pleistocene of southern Italy, with description of new species. Bollettino della Società Paleontologica Italiana, 44:11-24.

Santana, F.T., Ramalho, L.V., and Guimarães, C.R.P. 2009. New species of Metrarabdotos (Bryozoa, Ascophora) from Brazil. Zootaxa, 2222:57-65.

Smitt, F.A. 1868. Kritisk förteckning öfver Skandinaviens Hafs-Bryozoer. IV. Öfversigt af Kongliga VetenskapsAkademiens Förhandlingar, 1867, 24(6):3-230.

Távora, V.A. and Fernandes, J.M.G. 1994. Uma faunula de briozoários da Formação Pirabas (Mioceno Inferior) - Estado do Pará. Acta Geologica Leopoldensia, 39:145-156.

Távora, V.A. and Fernandes, J.M.G. 1999. Estudio de los foraminiferos de la Formación Pirabas (Mioceno Inferior), Estado do Pará, Brasil y su correlación com faunas Del Caribe. Revista Geologica de America Central, 22: 63-74.

Távora, V.A., Imbeloni, E.F.F., Cacela, A.S.M., and Baia, N.B. 2004. Paleoinvertebrados. In Rossetti, D.F. and Góes, A.M. (eds.), O Neógeno da Amazônia Oriental. Coleção Friederich Katzer, Belém, Editora do Museu Paraense Emílio Goeldi.

Távora, V.A., Nunes, S.S., and Souza, K.S. 2013. Paleoecologia da Formação Pirabas (Mioceno Inferior), Estado do Pará. Contribuições à Geologia da Amazônia, Sociedade Brasileira de Geologia Núcleo Norte, 8:235-251.

Távora, V.A. and Reis, S.B. 2015. Paleoinvertebrados e Paleoambientes da Formação Pirabas (Mioceno Inferior) em Aricuru, Município de Maracanã, Estado do Pará, Brasil. Anuário do Instituto de GeociênciasUFRJ, 38(1):31-39.

Távora, V.A., Santos, A.A.R., and Araújo, R. 2010a. Localidades fossilíferas da Formação Pirabas (Mioceno Inferior). Boletim do Museu Paraense Emílio Goeldi. Ciencias Naturais, 5:207-224.

Távora, V.A., Santos, A.A.R., and Nogueira Neto, I.L.A. 2010b. Eventos biológicos da Formação Pirabas (Mioceno Inferior). Revista Brasileira de Geociências, 40:256-264.

Vigneaux, M. 1949. Révision des Bryozoaires néogènes du Bassin d'Aquitaine et essai de classification. Mémoires de la Société Géologique de France, 28:1-153.

White, C. 1887. Contribuições a Paleontologia do Brasil. Arquivos do Museu Nacional, 7:1-273.

Winston, J.E., Vieira, L.M., and Woollacott, R.M. 2014. Scientific Results of the Hassler Expedition. Bryozoa. $\mathrm{N}^{\circ} 2$. Brazil. Bulletin of the Museum of Comparartive Zoology, 161:139-239.

Zagorsek, K., Ostrovsky, A.N., and Vavra, N. 2011. The new cheilostome bryozoan Metrarabdotos nehybai from the Middle Miocene of Moravia (Czech Repub- 
lic): palaeofaunistic, taxonomic and ontogenetic aspects. Neues Jahrbuch für Geologie und Paläontologie, 260:21-31.

Zagorsek, K., Ramalho, L.V., Berning, B., and Távora, V.A. 2014. A new genus of the family Jaculinidae
(Cheilostomata, Bryozoa) from the Miocene of the tropical western Atlantic. Zootaxa, 3838:98-112.

Zagorsek, K. and Vavra, N. 2000 A new method for the extraction of bryozoans from hard rocks from the Eocene of Austria. Jahrbuch der Geologischen Bundesanstalt, 142:249-258. 